\title{
Investigation of the effects of peppermint (Mentha piperita) on the biochemical and anthropometric profile of university students
}

\author{
Investigação dos efeitos do uso da hortelã (Mentha piperita) no \\ perfil bioquímico e antropométrico de estudantes universitários
}

\author{
Sandra Maria BARBALHO ${ }^{1,2 *}$, Flávia Maria Vasques Farinazzi MACHADO², Marie OSHIIWA², \\ Marcio ABREU ${ }^{3}$, Ellen Landgraf GUIGER ${ }^{1}$, Paschoal TOMAZELA ${ }^{3}$, Ricardo Alvares GOULART ${ }^{3}$
}

\begin{abstract}
The hypolipidemic effects of several medicinal plants have already been demonstrated, but many plants commonly used to treat diseases still need to be studied. Peppermint (Mentha piperita) is widely consumed by the population for different purposes, but not for the treatment of dyslipidemias. The objective of this study was to examine the effects of this plant on human biochemical and anthropometric profiles and blood pressure, based on the administration of peppermint juice twice daily for 30 days. Blood samples were collected before and after the treatment in order to determine the glycemic and lipid profiles, and the Body Mass Index (BMI) analysis was performed. Results indicated that $41.5 \%$ of the subjects showed a reduction in glycemia, $66.9 \%$ in total cholesterol levels, $58.5 \%$ in triacylglycerides, $52.3 \%$ in LDL-c (low-density lipoproteins) indices, $70 \%$ in GOT (glutamic-oxaloacetic transaminase) levels, $74.5 \%$ in GPT (glutamic-pyruvic transaminase) levels, and that $52 \%$ presented an increase in HDL-c (high-density lipoprotein cholesterol) indices. Also, 52.5\% showed a decrease in blood pressure and $48.7 \%$ in BMI. The use of peppermint by humans can be considered beneficial in the prevention and treatment of risk factors of chronic degenerative diseases.
\end{abstract}

Keywords: mentha piperita; dyslipidemias; metabolic syndrome; blood pressure.

\section{Resumo}

Os efeitos hipolipidêmicos de algumas plantas medicinais já foram demonstrados, mas muitas comumente utilizadas para o tratamento de doenças precisam ser estudadas. A hortelã (Mentha piperita) é requisitada pela população com diferentes finalidades, mas não no tratamento de dislipidemias. Objetivou-se verificar os efeitos desta planta no perfil bioquímico e antropométrico, e na pressão arterial de seres humanos, a partir da administração de suco de hortelã duas vezes ao dia, durante 30 dias. Antes e após tratamento, foram colhidas amostras de sangue para determinação do perfil glicêmico e lipídico, além de análise de Índice de Massa Corpórea. Os resultados mostraram que 41,5\% das pessoas apresentaram redução na glicemia, 66,9\% nos níveis de colesterol, 58,5\% nas taxas de triacilglicerídeos, 52,3\% nos índices de LDL-c (lipoproteínas de baixa densidade), 70\% nos níveis de TGO (transaminase glutâmica oxalacética), 74,5\% nos níveis de TGP (transaminase glutâmica pirúvica) e 52\% apresentaram aumento nos índices de HDL-c (lipoproteína de alta densidade). Em 52,5\% houve diminuição de pressão arterial e redução do IMC em 48,7\%. A utilização da hortelã para humanos pode ser considerada benéfica na prevenção e tratamento de fatores de risco de doenças crônico-degenerativas.

Palavras-chave: mentha piperita; dislipidemias; síndrome metabólica; pressão arterial.

\section{Introduction}

The literature is rich in studies that demonstrate a relationship between high levels of blood lipids, insulin resistance and high blood pressure with increased risk of developing cardiovascular diseases. Many medicinal plants are effective in the treatment of risk factors for the development of these diseases. Mentha piperita, commonly known as peppermint, is a plant used extensively by people for the most diverse purposes, but not for the treatment of the aforementioned risk factors. Medicinal plants have also been applied in the treatment of several metabolic diseases, especially in the control of Diabetes mellitus and Hypercholesterolemia (PRAKASAM et al., 2003; WILLCOX et al., 2003; MOST et al.,
2005; RUKKUMANI et al., 2003; HAN et al., 2008; KWON et al., 2009).

It is known that western diets, especially that of Brazilians, contain increasingly high concentrations of saturated fats, favoring increased levels of total cholesterol, triacylglycerides, low HDL-c, high blood pressure and altered fasting glycemia, which determine increased risks of developing heart diseases (SCHAAN et al., 2004; CAPUZZI; FREEMAN, 2007; MERCHANT et al., 2007). Besides these factors, there are the pharmaceutical cholesterol-lowering drugs, which are expensive and involve a possible long-term use of the drugs.

Received 30/3/2009

Accepted 27/4/2010 (004130)

${ }^{1}$ Faculdade de Medicina e Ciências da Saúde da Universidade de Marília - UNIMAR, Av. Higino Muzzi Filho, 1001, CEP 17525-902, Marília, SP, Brasil, e-mail: smbarbalho@terra.com.br

${ }^{2}$ Faculdade de Tecnologia de Marília - FATEC “Estudante Rafael Almeida Camarinha”, Av. Castro Alves, 62, Bairro Somenzari, Marília, SP, Brasil

${ }^{3}$ Faculdade de Medicina de medicina de Marília - FAMEMA

${ }^{*}$ Corresponding author 
Mentha piperita has numerous pharmacological, cosmetic and alimental applications due to its ability to produce terpene and terpenoid compounds. This plant produces oils rich in menthol and flavonoids, making it economically very important (MARTINS et al., 1998; CARDOSO et al., 2001; McKAY; BLUMBERG, 2006; SOUSA et al., 2007).

As previously mentioned, several plants have been evaluated for their potential to lower plasma lipid levels, but reports on the role of peppermint (Mentha piperita) are restricted to its antispasmodic, antimutagenic and antiflatulent effects, as well its antiemetic and analgesic effects on the mucous membranes (MEI et al., 2002; MIMICA-DUKIC et al., 2003; ROMERO-JIMENEZ et al., 2005).

The purpose of the present work was to examine the effects of peppermint juice on the biochemical and anthropometric profile and blood pressure of humans.

\section{Materials and methods}

\subsection{Study site and population}

This work was carried out at the "Estudante Rafael Almeida Camarinha" Faculty of Technology in Marilia, State of Sao Paulo, Brazil. The study population comprised 25 students between 18 and 45 years old, chosen randomly to participate in the project.

\subsection{Anthropometric evaluation}

Anthropometric measurements were taken and evaluated according to the methodology proposed by the World Health Organization (WHO, 1995). Weight and stature were measured, respectively, on an electronic scale (Filizola) with capacity for $180 \mathrm{~kg}$ and a stadiometer (SANNY) with millimetric precision.

The anthropometric measuring techniques presented below were based on Heyward and Stolazarczyk (2000).

- Stature. The subject must be barefoot, standing erect, feet together, with the heels, knees, buttocks, back and head flat against the wall, according to the Frankfort plane, with the lower limit of the orbit on the same horizontal line as the upper margin of the external auditory meatus, arms hanging freely against the trunk. The movable headboard of the stadiometer is positioned firmly on the upper part of the head, lightly pressing the hair;

- Weight. Measurements shall be in kilograms. People should be weighed wearing a minimum of clothing and no shoes. The subject must stand in the middle of the scale, with the arms relaxed along the trunk and the feet slightly apart. The weight is then read in grams.

\subsection{Biochemical measurements}

Glycemia, total cholesterol, HDL, triacylglycerides, GOT, GPT, and urea were measured before and after the treatment (30 days) with peppermint juice, according to the methodology adopted by the Marilia Municipal Foundation for Higher Education, at its Clinical Pathology Laboratory. The results were interpreted according to Mancini and Medeiros (2005), and the SBD - 'Sociedade Brasileira de Diabetes' (2010).

\subsection{Statistical methodology}

The data were described by Descriptive Statistics and analyzed by Student's $t$-test, comparing the two moments of the study.

\subsection{Legal ethical aspects}

Approval was given by the Research Ethics Committee of FAMEMA (Marilia Faculty of Medicine), under the Protocol No. 698 of November 5, 2007. Only individuals who had signed a consent form participated in the study (Resolution 196/October 10, 1996 - National Health Council).

\subsection{Preparation of peppermint juice}

Extracts were prepared in the form of juice (leaves blended with water and sieved), in a concentration of $20 \mathrm{~g}$ of peppermint leaves $/ 200 \mathrm{~mL}$ of water distilled daily. The doses were also administered daily, including weekends, and consisted of the ingestion of one $200 \mathrm{~mL}$ glass of juice in the morning and another in the afternoon by a man weighing $70 \mathrm{~kg}$.

\section{Results and discussion}

The results indicated that $41.5 \%$ of the study population showed a decrease in glycemia, $66.9 \%$ in total cholesterol levels, $58.5 \%$ in triacylglyceride rates, $52.3 \%$ in LDL-c indices, $70 \%$ in GOT levels, $74.5 \%$ in GPT levels, and 69.3\% in urea levels, while $52 \%$ presented an increase in HDL-c indices. Among the studied group, $52.5 \%$ showed lowered blood pressure, $43.8 \%$ presented weight loss, and $48.7 \%$ showed reduced BMI.

The analysis of Table 1 reveals a statistically significant difference in maximum BP (decrease), LDL-c, GOT and urea levels. Total cholesterol and triacylglycerides were also lower, albeit not statistically significant.

Based on the results listed in Table 1, a parallel can be drawn between the genders (male and female) and the moment of measurement (pre- and post-treatment). The women showed a statistically significant difference in TC levels (decrease), GOT (decrease) and urea (decrease), and numerically, LDL-c and GPT were lower while HDL-c was increased. The men showed a statistically significant difference in GOT levels (decrease) and a non-significant decrease in total cholesterol, LDL-c and urea.

The results of this work are related to other studies that use vegetable foods for glycemic and lipid control, aiming at the prevention and treatment of chronic degenerative diseases (CAMACHO, 1996; JORGE et al., 1998; SONG; LEE, 2003; FIGUEIREDO; MODESTO-FILHO, 2008). These diseases are on the rise, for the globalized economy has led to new worldwide trends in the nutritional sector, contributing toward rapid changes in dietary patterns, with increasing consumption of foods rich in fats and sugars and a decline in the consumption of foods essential to health and in the practice of physical activities. This tendency is manifested by increased body weight and the 
Peppermint and its effects on metabolic profile

Table 1. Medium, standard deviation and results of the statistical analysis of the biochemical variables.

\begin{tabular}{|c|c|c|c|}
\hline \multirow[t]{2}{*}{ Variables } & \multicolumn{2}{|c|}{ Moment } & \multirow[t]{2}{*}{ p-value } \\
\hline & Pre-treatment & Post-treatment & \\
\hline Total cholesterol $\left(\mathrm{mg} \cdot \mathrm{dL}^{-1}\right)$ & $186.64 \pm 40.95$ & $175.21 \pm 33.86$ & 0.1785 \\
\hline LDL-c & $167.36 \pm 46.94$ & $132.60 \pm 49.87$ & 0.0163 \\
\hline Glycemia (mg.dL $\left.{ }^{-1}\right)$ & $89.41 \pm 9.11$ & $88.77 \pm 7.54$ & 0.1819 \\
\hline HDL-c $\left(m g \cdot d^{-1}\right)$ & $47.10 \pm 15.48$ & $44.85 \pm 16.60$ & 0.4093 \\
\hline GOT (U.L-1) & $25.32 \pm 4.62$ & $22.00 \pm 6.44$ & 0.0030 \\
\hline GPT $\left(\mathrm{U}^{-L^{-1}}\right)$ & $38.73 \pm 8.66$ & $37.90 \pm 12.43$ & 0.3185 \\
\hline Triglycerides $\left(\mathrm{mg} \cdot \mathrm{dL}^{-1}\right)$ & $128.41 \pm 72.02$ & $111.65 \pm 65.37$ & 0.1955 \\
\hline Urea $\left(\mathrm{mg} \cdot \mathrm{dL}^{-1}\right)$ & $29.36 \pm 8.94$ & $27.10 \pm 8.60$ & 0.0123 \\
\hline Weight (Kg) & $77.84 \pm 17.90$ & $79.79 \pm 17.80$ & 0.1365 \\
\hline $\mathrm{BP} \max$ & $121.90 \pm 17.78$ & $112.86 \pm 8.95$ & 0.0101 \\
\hline $\mathrm{BP} \min$ & $79.52 \pm 12.44$ & $79.05 \pm 10.91$ & 0.4265 \\
\hline
\end{tabular}

development of dyslipidemias, diabetes, arterial hypertension, obesity, metabolic syndrome (MS) and vascular diseases (MANCO et al., 2004; MERCHANT et al., 2007; HOENIG, 2008; HSIEH et al., 2008; FRICK et al., 2008).

Preventive measures such as nutritional assistance and education, as well as the fight against physical inactivity, are extremely important factors to prevent the rise in the incidence of MS and its chronic complications (MIGGIANO; PETRAROLI, 2005). However, alternatives may be important aids in the prevention and even minimization of risk factors of future diseases. These alternatives include medicinal plants. Figueiredo and Modesto-Filho (2008) determined the effects of defatted sesame (Sesamum indicum L.) flour on the glycemic levels and weight control of diabetes type 2 patients. Soy (SONG; LEE, 2003) and eggplant (CAMACHO, 1996; JORGE et al., 1998) have been widely studied and their consumption has been associated with beneficial effects on dyslipidemias.

Other examples are Cassia esculenta, Curcuma sp., Ananas comosus, green tea and others (PRAKASAN et al., 2003; RUKKUMANI et al., 2003). Sousa et al. (2007) determined and quantified the antioxidant effects of phenolic compounds of the bark and leaves of several medicinal species, among them T. brasiliensis, T. fagifolia, Q. grandiflora and C. macrophyllum. Similarly to this work, there are reports in the literature that demonstrate that the use of plants may be related with reduced BMI. Maskarinec et al. (2008) made this association with the use of soybean in adult women, and Ortega and co-workers et al. (2006) reported this relationship with the consumption of vegetables and cereals.

Mentha piperita is one of ten plants most widely consumed by the population for therapeutic purposed and the consumption of its juice in the present study showed that it can be efficient in controlling glycemia, total cholesterol, triacylglycerides and LDL-c, as well as in increasing HDL-c (BARBALHO et al., 2009) without interfering with hepatic enzymes (GOT and GPT), which could indicate attack on the liver. Moreover, no increase was observed in urea levels, indicating that it does not promote renal alterations.

Several studies have focused on examining the beneficial effects of Mentha species. These effects may be related with the presence of substances such as menthol, eugenol, thymol, flavonoids, terpenoids, eriotricin, luteolin and hesperidin rosmarinic, cinnamic and caffecic acids and other compounds that demonstrate antioxidant activity (McKAY; BLUMBERG, 2006; SAMARTH et al., 2007; DORMAN et al., 2009; SCHMIDT et al., 2009; YANG et al., 2010). López et al. (2009) determined the effects of the genus Mentha (Mentha piperita and Mentha aquatica) extracts and observed protection of the PC12 cells against oxidative hydrogen-peroxide-induced stress.

Many studies indicate that the consumption of foods and beverages with polyphenol is related to protection against cardiovascular diseases. This is related to their antioxidant potential and it is also because of its action on the nitric oxide (NO) metabolism - that improves the vascular tone control, and it is also due to its action on the hypertension (SCHINI-KERTH et al., 2010).

The antioxidants also contribute to the reduction of oxidative stress in obese and diabetic persons (BEN SLAMA et al., 2009; MAHFOUZ et al., 2009; BENZIE; WACHTEL-GALOR, 2010). Flavonoids may act in distinct ways on various components of plasma lipid (DOYAMA et al., 2005), but the available literature still does not suffice to explain the exact mechanisms whereby phenolic acids, flavonoids and terpenoids exert these beneficial effects. Nor does it explain the reasons why they may have positive effects on the reduction of BMI. Raederstorff (2009) showed that olive polyphenols can decrease oxidized LDL-c levels in plasma and reduce oxidative damage.

In view of the need to find inexpensive alternatives to conventional medications, studies are necessary to confirm the effects of medicinal plants and the ideal therapeutic schemes of benefits and the reduction of the occurrence of adverse effects, since in Brazil's poorest regions and even in its largest cities, medicinal plants are sold in open street markets and municipal markets and are grown in people's backyards (MACIEL et al., 2002).

The results obtained in this work are important because they indicate that Mentha piperita can be used for therapeutic and preventive purposes on the biochemical profile, blood pressure and BMI. 


\section{Conclusions}

The use of peppermint in the form of juice for humans can be considered beneficial in the prevention and treatment of risk factors of diseases that rank among the main causes of death in the globalized world. Therefore, it is possible to suggest that this plant can be used as a functional ingredient to the food processing industry such as snacks, cereal bars, drinks and blends. This can be attractive to the consumers who are interested in meals with more benefits than the usual.

\section{Acknowledgements}

The authors are grateful to the people who took part in our study and to the nurses who collected blood from the patients.

\section{References}

BARBALHO, S. M. et al. Mentha piperita effects on Wistar rats plasma lipids. Brasilian Archives of Biology and Technology, v. 52, n. 5, p. 1137-1143, 2009. http://dx.doi.org/10.1590/S151689132009000500011

BEN SLAMA, F. et al. Vitamins A, E and leptin in obese and non-insulin-dependent diabetes group. La Tunisie medicale, v. 87, n. 11, p. 726-730, 2009. PMid:20209828

BENZIE, I.; WACHTEL-GALOR, S. Vegetarian Diets and Public Health: Biomarker and Redox Connections. Antioxidants and Redox Signaling, v. 13, n. 10, p. 1575-91, 2010. http://dx.doi. org/10.1089/ars.2009.3024

CAMACHO, R. Ação da berinjela (Solanum melongena) sobre o nível de colesterol plasmático em coelhos. 1996. 37 f. Monografia (Graduação em Ciências Biológicas)-Universidade Estadual de Londrina, Londrina, 1996.

CAPUZZI, D. M.; FREEMAN, J. S. C-Reactive Protein and cardiovascular risk in the metabolic syndrome and type 2 diabetes: controversy and challenge. Clinical Diabetes, v. 25, n. 1, p. 16-22, 2007. http://dx.doi.org/10.2337/diaclin.25.1.16

CARDOSO, M. G. et al. Metabólitos secundários vegetais: visão geral química e medicinal. Lavras: UFLA, 2001.

DORMAN, H. J. et al. Phenolic profile and antioxidant evaluation of Mentha $\times$ piperita L. (peppermint) extracts. Natural Product Communication, v. 4, n. 4, p. 535-42, 2009.

DOYAMA, J. T. et al. Chemical investigation and effects of the tea of Passiflora alata on biochemical parameters in rats. Journal of Ethnopharmacology, v. 96, n. 3, p. 371-4, 2005. http://dx.doi. org/10.1016/j.jep.2004.06.021

FIGUEIREDO, A. S.; MODESTO-FILHO, J. Efeito do uso da farinha desengordurada do Sesamum indicum $L$ nos níveis glicêmicos em diabéticas tipo 2. Revista Brasileira de Farmacognosia, v. 18, n. 1, p. 77-83, 2008.

FRICK, K. D.; SORENSEN, S. V.; HOLLENBEAK, C. How Inducing Covariation in Simulated HDL-C, Triglyceride, and Total Cholesterol Data Affects Framingham Risk Equation Results. Value in Health, v. 11, n. 5, p. 939-945, 2008. http://dx.doi.org/10.1111/ j.1524-4733.2008.00333.x

HAN, C.; HUI, Q.; WANG, Y. Hypoglycaemic activity of saponin fraction extracted from Momordica charantia in PEG/salt aqueous two-phase systems. Natural product research, v. 22, n. 13, p. 1112-1119, 2008. PMid:18855210. http://dx.doi.org/10.1080/14786410802079675
HEYWARD, H. V., STOLAZARCZYK, M. L. Métodos de dobras Cutâneas In: HEYWARD, H. V. Avaliação da composição corporal aplicada. São Paulo: MANOLE, 2000.

HOENIG, M. R. Implications of the obesity epidemic for lipidlowering therapy: non-HDL cholesterol should replace LDL cholesterol as the primary therapeutic target. Vascular Health and Risk Management, v. 4, n. 1, p. 143-156, 2008. PMid:18629364. PMCid:2464759. http://dx.doi.org/10.2147/vhrm.2008.04.01.143

HSIEH C. H. et al. The impact of metabolic syndrome on insulin sensitivity, glucose sensitivity, and acute insulin response after glucose load in early-onset type 2 diabetes mellitus: Taiwan Early-Onset Type 2 Diabetes Cohort Study. Metabolism, v. 57, n. 11, p. 1615-1621, 2008. PMid:18940402. http://dx.doi.org/10.1016/j. metabol.2008.07.017

JORGE P. A. et al. Effect of eggplant on plasma lipid levels, lipidic peroxidation and reversion of endothelial dysfunction in experimental hypercholesterolemia. Arquivos Brasileiros de Cardiologia, v. 70, n. 2, p. 87-91, 1998. PMid:9659714. http://dx.doi. org/10.1590/S0066-782X1998000200004

KWON, D. Y. et al. Long-term consumption of saponins derived from Platycodi radix (22 years old) enhances hepatic insulin sensitivity and glucose-stimulated insulin secretion in $90 \%$ pancreatectomized diabetic rats fed a high-fat diet. The British journal of nutrition, v. 101, n. 3, p. 358-366, 2009. PMid:18577298. http://dx.doi. org/10.1017/S000711450801218X

LÓPEZ, V. et al. Neuroprotective and neurochemical properties of mint extracts. Phytotherapy Research, v. 24, p. 869-874, 2009.

MACIEL, M. A. M.; PINTO, A. C.; VEIGA, V. F. Plantas Medicinais: a necessidade de estudos multidisciplinares. Química Nova, v. 25 , n. 3, p. 429-438, 2002. http://dx.doi.org/10.1590/S010040422002000300016

MAHFOUZ, M. M.; ZHOU, S. Q.; KUMMEROW, F. A. Vitamin B6 Compounds are Capable of Reducing the Superoxide Radical and Lipid Peroxide Levels Induced by $\mathrm{H} 2 \mathrm{O} 2$ in Vascular Endothelial Cells in Culture. International Journal for Vitamin and Nutrition Research, v. 79, n. 4, p. 218-29, 2009. PMid:20209473. http://dx.doi. org/10.1024/0300-9831.79.4.218

MANCINI, M. C.; MEDEIROS, M. A. Como diagnosticar e tratar Diabetes mellitus. Revista Brasileira Medicina, v. 62, n. 4, p. 115-120, 2005.

MANCO, M.; CALVANI, M.; MINGRONE, G. Effects of dietary fatty acids on insulin sensitivity and secretion. Diabetes, Obesity and Metabolism, v. 6, n. 6, p. 402-413, 2004. PMid:15479216. http:// dx.doi.org/10.1111/j.1462-8902.2004.00356.x

MARTINS, A. P. et al. Essential oils from four Piper species. Phytochemistry, v. 49, p. 2019-2023, 1998. http://dx.doi. org/10.1016/S0031-9422(98)00391-4

MASKARINEC, G. et al. Soy intake is related to a lower body mass index in adult women. European Journal of Nutrition, v. 47 , n. 3, p. 138-44, 2008. PMid:18427855. PMCid:2674433. http://dx.doi.org/10.1007/s00394-008-0707-x

McKAY, D. L.; BLUMBERG, J. B. A review of the bioactivity and potential health benefits of peppermint tea (Mentha piperita L.). Phytotherapy Reserarch, v. 20, n. 8, p. 619-33, 2006. PMid:16767798. http://dx.doi.org/10.1002/ptr.1936

MEI, L. et al. Muscle Relaxing Activity of Hyssopus officinalis Essential Oil on Isolated Intestinal Preparations. Planta Medica, v. 10, n. 1055, p. 213-216, 2002.

MERCHANT, A. T. et al. Diet, physical activity, and adiposity in children in poor and rich neighbourhoods: a cross-sectional 
comparison. Nutrition Journal, v. 6, n. 1, p. 1475-2891, 2007. PMid:17217531. PMCid:1779798. http://dx.doi.org/10.1186/14752891-6-1

MIGGIANO, G.; PETRAROLI, M. Metabolic response to food and diet in paediatric obesity. La Clinica terapeutica, v. 156, n. 5, p. 235-239, 2005.

MIMICA-DUKIC, N. et al. Antimicrobial and antioxidant activities of three Mentha species essential oils. Planta Medica, v. 69, n. 5, p. 413-419, 2003. PMid:12802721. http://dx.doi. org/10.1055/s-2003-39704

MOST, M. M. et al. Rice bran oil, not fiber, lowers cholesterol in humans. American Journal Clinical Nutrition, v. 81, n. 1, p. 64-68, 2005. PMid:15640461

ORTEGA, R. M. et al. Responses to two weight-loss programs based on approximating the diet to the ideal: differences associated with increased cereal or vegetable consumption. International Journal for Vitamin and Nutrition Research, v. 76, n. 6, p. 367-76, 2006. http://dx.doi.org/10.1024/0300-9831.76.6.367

PRAKASAM, A.; SETHUPATHY, S.; PUGALENDI, K. V. Hypolipidaemic effect of Casearia esculenta root extracts in streptozotocin-induced diabetic rats. Pharmazie, v. 58, n. 11, p. 828-832, 2003.

RAEDERSTORFF, D. Antioxidant activity of olive polyphenols in humans: a review. International Journal for Vitamin and Nutrition Research, v. 79, n. 3, p. 152-65, 2009. PMid:20209466. http://dx.doi.org/10.1024/0300-9831.79.3.152

ROMERO-JIMENEZ, M. et al. Genotoxicity and anti-genotoxicity of some traditional medicinal herbs. Mutation Research, v. 1, n. 1, p. 147-55, 2005.

RUKKUMANI, R.; SRI BALASUBASHINI, M.; MENON, V. P. Protective effects of curcumin and photo-irradiated curcumin on circulatory lipids and lipid peroxidation products in alcohol and polyunsaturated fatty acid-induced toxicity. Phytotherapy Research, v. 17, n. 8, p. 925-929, 2003. PMid:13680826. http:// dx.doi.org/10.1002/ptr.1254
SAMARTH, R. M. Protection Against Radiation Induced Hematopoietic Damage in Bone Morrow of Swiss Albino Mice by Mentha piperita (linn). Journal of Radiation Research, v. 48, n. 6, p. 523-528, 2007. PMid:17938557. http://dx.doi.org/10.1269/jrr.07052

SCHAAN, B.; D'AGORD HARZHEIM, E.; GUS, I. Perfil de risco cardíaco no diabetes mellitus e na glicemia jejum alterada. Revista de Saúde Pública, v. 38, v. 4, p. 529-536, 2004.

SCHINI-KERTH, V. B. et al. Nutritional improvement of the endothelial control of vascular tone by polyphenols: role of NO and EDHF. Pflügers Archiv, v. 459, n. 6, p. 853-62, 2010. PMid:20224869. http://dx.doi.org/10.1007/s00424-010-0806-4

SCHMIDT, E. et al. Chemical composition, olfactory evaluation and antioxidant effects of essential oil from Mentha $\times$ piperita. Natural Product Communications, v. 4, n. 8, p.1107-1112, 2009.

SOCIEDADE BRASILEIRA DE DIABETES - SBD. Atualização brasileira sobre diabetes. Sociedade Brasileira de Diabetes, 2010. Disponível em: <www.sbd.br>.

SONG, T.; LEE, S. O. Soy protein with or without isoflavones, soy germ and soy germ extract, and daidzein lessen plasma cholesterol levels in golden Syrian hamsters. Experimental biology and medicine, v. 228, n. 9, p. 1063-1068, 2003.

SOUSA, C. M. M. et al. Fenóis totais e atividade antioxidante de cinco plantas medicinais. Química Nova, v. 30, n. 2, p. 351-355, 2007. http://dx.doi.org/10.1590/S0100-40422007000200021

WILLCOX, J. K.; CATIGNANI, G. L.; ROBERTS, L. J. Dietary flavonoids fail to suppress F2-isoprostane formation in vivo. Free Radical Biology and Medicine, v. 34, n. 7, p. 795-799, 2003. http:// dx.doi.org/10.1016/S0891-5849(02)01425-9

WORLD HEALTH ORGANIZATION - WHO. Physical Status: The use and interpretation of anthropometry. Geneva: WHO, 1995.

YANG, S. A. et al. Comparative study of the chemical composition and antioxidant activity of six essential oils and their components. Natural Product Research, v. 24, n. 2, p. 140-51, 2010. http://dx.doi. org/10.1080/14786410802496598 